\title{
The Views of School Managers about Decision Making Authorities in the Field of Education and Decentralization*
}

\author{
Süleyman KARATAŞ ${ }^{* *}$ \\ Ahu TAŞ ${ }^{* * * *}$
}

\author{
Yeşim EŞBERK BAŞYAYLA ${ }^{* * *}$ \\ Beyza TOPÇU $\mathbf{U}^{* * * * *}$
}

Received: 19 January 2016

Accepted: 26 February 2016

\begin{abstract}
The aim of this study is to find out the views of school managers about decentralization. With this study, we aim to contribute to the discussions on centralization, decentralization and school-based management. The universe of the study includes 423 school managers from state primary, secondary and high schools in the center of Antalya. The sample of the study includes 151 school managers from state primary, secondary and high schools in the center of Antalya. Convenience sampling method is used. The data are collected with the scale developed by Çınkır (2010) and called 'The Scale of Decentralization of Education'. Percent and frequency calculations are done in data analysis. According to the findings of this study the highest frequency in all dimensions is the unit of government. But from the holistic point of view of organization of schools, the highest frequency unit is school (387/\%28.4) Finally, there are some offers about the views of school managers on being involved in the decisions related to education.
\end{abstract}

Keywords: education, decentralization, school managers, centralization, school-based management.

\section{Extended Abstract}

Purpose and Significance: The governance mentality, in which decision making power or potency in every sense is centralized, is called centralization. Centralization can also be defined as the organisation that the top of organization has the authority, while the provincial units have the responsibility. Centralization has some advantages; unity and cooperation is provided in terms of income and evaluation of expenses. The supremacy of civilian management over the military forces, the impartiality of administration and public servants, balanced distribution of the sources and the expert staff are easily provided. The disadvantages of centralization are as follows; stationery (bureaucracy) increases; it is not suitable for democracy (participatory and pluralistic management). The officials in the centre can provide privileges to their zones/regions in terms of income

\footnotetext{
* This study was presented at "10. Ulusal Eğitim Yönetimi Kongresi” (10 $10^{\text {th }}$ National Education Administration Congress) held in Gaziantep, Turkey between 7 and 9 May, 2015.

** Corresponding Author: Assist. Prof. Dr., Akdeniz University, Antalya, Turkey, skaratas07@gmail.com

***Teacher, Master's Student, Ministry of National Education, Antalya, Turkey

**** Teacher, Master's Student, Ministry of National Education, Antalya, Turkey

****** Teacher, Master's Student, Ministry of National Education, Antalya, Turkey
}

\section{Citation Information}

Karataş, S., Eşberk-Başyayla, Y., Taş, A., \& Topçu, B. (2017). Okul yöneticilerinin eğitimle ilgili kararlara katılmada karar mercileri ve yerinden yönetim anlayışına ilişkin görüşleri. Kuramsal Eğitimbilim Dergisi [Journal of Theoretical Educational Science, 10(1), 73-94. 
distribution. The needs of local people can be ignored. To be able to control and administrate all the country and the society may increase the public expenditure. Decentralization is the governance of the services from where they are executed and the things from where they are done. The functions in management's hands such as planning, decision-making, collection of public revenues are partially transferred to provincial organizations, the local governments, semi-autonomous public institutions, professional organizations and voluntary organizations. In decentralization mentality, the basic approach is to fulfil the services through the country faster and more fluently. The central government practices appointment of the servants. Some disadvantages of the decentralization are; difficulties in monitoring a single policy and coordinated renovation, loss of the authority, the unequal distribution of service quality all over the country and financial disorders. Some advantages of the decentralization are as follows; benefitting from qualified labour at the local level is easier; sharing of issues among local organizations and governors and thus, solving them is easier; there has been a dynamic system. This study aims finding out the views of school managers about decentralization. The identification of school managers' views related to decentralization of education is based on these views; the better understanding of the difference between decentralization approach and other government approaches especially the understanding of the advantages and the disadvantages of education decentralization.

Methods: The universe of this study consists of 423 state primary, secondary, and high school managers in the center of Antalya province and the sample, which is chosen with the convenience sampling method, includes 151 of them. The study has been done between 2014-2015 years. The data of the study is collected with "The scale of Decentralization of Education" developed by Cinkır (2010). In this scale, there are six main decision categories and sub categories of decision-making. The main categories are; governance, organization of school, human resources management, education programs and teaching, measurement and evaluation, finance of education. In this scale, the units such as the ministry, the region, the province, the district, the municipality, and the school are presented as the decision-making authority choices. In data analyzing process, percentages and frequencies are calculated by using the SPSS program. Chisquare analysis is used to put forth the relationship between the views of school managers about decentralization and seniority. The level of significance is taken as .05 .

Results: The analyses are made through the frequency calculations of 6 categories and the units suggested for each heading by newly appointed school managers. The unit, which has the highest frequency that school managers deem suitable for decision makers in decisions relating to the management dimension, is the ministry $(42.7 \%)$ whereas the region has the lowest frequency

$(5.4 \%)$. The unit, which has the highest frequency that school managers deem suitable for decision makers in decision relating to the dimension of school organization (28.4\%), however the municipality has the lowest frequency $(4.12 \%)$. The unit which has the highest frequency (24\%) that school managers approve for decision making authority in 
decisions related to management of human resources is the province whereas the opposite unit is the municipality with $2.92 \%$ of frequency. The unit which has the highest frequency with $18.5 \%$ that managers think suitable for decision makers in decisions relating to educational programs and teaching dimension is the province whereas the municipality has the lowest (2.6\%) frequency. The unit with the highest frequency of $57.4 \%$ related to measurement and evaluation is the ministry while the school has the lowest frequency (12\%). The province has the highest frequency with $39.8 \%$ by the school managers seen as the authority for decision making, the opposite unit is the region with the frequency of $3.46 \%$. There is significant difference between the school managers' views about decentralization and the variable of seniority regarding to making decisions on the salaries of the employees of education.

Discussion and Conclusions: This study has the similar results with the study of "Opinions of School Principals about Local Management" by Turan, Yucel, Karatas and Demirhan (2010) and the study of "An Application in The Process of Educational Administration's Localization: Educational Regions Advisory Committee" by Olmez and Tonbul (2011). All of them show that the system has not been ready for the decentralization of education. When the results are evaluated, we can see that the managers of our sample mostly see the Ministry, the School, and the Province as the decision makers about education. The Region, the District, and the Municipality are seen not to have been given task. This may be because the managers give countenance to decentralization. That Turkey has a unitary structure of government, may be the reason for them to give importance to central government. It may be the thought that the newly appointed school managers lack information about decentralization of education and devolution of authority. For determination of the possible problems and any need for infrastructural features, the pilot trial zones should be constituted from the independent directorates (from districts and/or the provinces) during the process of the decentralization of education. In-service seminars, conferences and panels should be given regarding to the decentralization of education and the delegation of authority through the academicians, and active participation should be assured. 


\section{Okul Yöneticilerinin Eğitimle İlgili Kararlara Katılmada Karar Mercileri ve Yerinden Yönetim Anlayışına İlişkin Görüşleri*}

\author{
Süleyman KARATAŞ ${ }^{* *}$ \\ Ahu TAŞ****
}

\author{
Yeşim EŞBERK BAŞYAYLA*** \\ Beyza TOPÇU $\mathbf{U}^{* * * * *}$
}

Makale Gönderme Tarihi: 19 Ocak 2016

Makale Kabul Tarihi: 26 Şubat 2016

ÖZ: $\mathrm{Bu}$ çalışmanın amacı eğitimin yerinden yönetimi konusunda eğitim kurumlarında görev yapan eğitim yöneticilerinin yerinden yönetim anlayışına ilişskin görüşlerini tespit etmektir. Yapılan bu çalışma ile eğitim yöneticilerinin görüşleri doğrultusunda merkeziyetçi, yerinden ve okula dayalı ögretim anlayışları hakkında yapılan çalışma ve tartışmalara katkıda bulunmak beklenilmektedir. Çalışmanın evrenini Antalya merkez ilçelerinde devlet (resmi) ilkokul, ortaokul ve liselerde görev yapan toplam 423 okul müdürü oluşturmaktadır. Çalışmanın örneklemi ise evrenden basit tesadüfî örnekleme yolu ile seçilen, yeniden ataması yapılan 151 (\%35) ilkokul, ortaokul ve lise okul müdürü oluşturmaktadır. Çalışmanın verileri Çınkır (2010) tarafından geliştirilen 'Eğitimin Yerinden Yönetim Ölçeği’ aracı ile toplanmıştır. Verilerin çözümlenmesinde istatistiksel analiz olarak yüzde- frekans ve ki-kare hesaplamaları yapılmıștır. Çalışmada tüm boyutlarda karar mercii olarak görülen en yüksek frekansa sahip birimin bakanlık olduğu tespit edilmiştir. Ayrıca çalışma eğitim yöneticilerinin kıdemleri artıkça eğitim işgörenlerine ödenecek ücretlerin kararlaştırılması konusunda belediyelere daha fazla anlam yükledikleri belirlenmiştir. Yine çalışmada sadece okulun örgütlenmesi boyutuna; okul müdürlerinin alınacak kararlarda karar mercii olarak uygun gördükleri birimin okul olduğu belirlenmiştir.

Anahtar kelimeler: eğitim, yerinden yönetim, okul müdürleri, merkeziyetçi yönetim, okula dayalı yönetim.

\section{Giriş}

Yönetim en genel anlamıyla ortak amaçlar doğrultusunda sistemli bir şekilde örgütü amaçlara ulaştırma becerisidir. Alan yazında merkeziyetçi, yerinden ve okula dayalı yönetim anlayışlarının eğitim politikalarının belirlenmesi, karar verme, planlama, örgütleme, koordinasyon, bütçeleme ve değerlendirme boyutlarında farklı görüşleri savundukları bilinmektedir. Ancak toplum düzenini ve kamusal hizmetleri sağlamak amacıyla devletin örgütlenmesine ilişkin, merkeziyetçilik ve yerinden yönetim (âdem-i merkeziyet) olmak üzere iki karşıt temel model en çok tartş̧ılan yönetim anlayışlarıdır. Bunlardan ilki tüm kamu hizmetlerinin tek merkezden, ikincisi ise farklı merkez ve kurumlar tarafından yürütülmesini benimsemektedir (Çınarlı, 2011).

Merkezi Yönetim anlayışı, kamu hizmetlerinde birlik ve bütünlüğü sağlamak üzere, söz konusu hizmetlere ilişkin karar ve uygulamaların merkezi hükümet veya onun hiyerarşik yapısı içerisinde yer alan organlarca yürütülmesidir (Aktan, 1994). Ülkede her anlamda karar verme gücünün ya da erkinin merkezde toplandığ 1 yönetim anlayışı, merkezi yönetim olarak tanımlanmaktadır (Tural, 2002). Merkezi yönetim, yetkinin, örgütün tepesinde, sorumluluğun ise taşra birimlerde toplandığı örgütler olarak da ifade

\footnotetext{
* Bu çalışma 7-9 Mayıs 2015 tarihlerinde gerçekleşen “10. Ulusal Eğitim Yönetimi Kongresi”nde sunulmuştur. ** Sorumlu Yazar: Yrd. Doç. Dr., Akdeniz University, Antalya, Turkey, skaratas07@gmail.com

***Öğretmen, Yüksek Lisans Öğrencisi, MEB, Antalya, Turkey

**** Öğretmen, Yüksek Lisans Öğrencisi, MEB, Antalya, Turkey

***** Öğretmen, Yüksek Lisans Öğrencisi MEB, Antalya, Turkey
} 
edilebilir. Merkezi yönetim yapısında, hiyerarşik olarak yukarıdan aşağıya emir ve yönergeler giderken, üst birim veya kişilere ise, yazılı metinler ve bu metinlere dayalı davranıldığını gösterir bilgi ve belgeler gitmektedir (Taşar, 2009).

Merkezden yönetimin yararları aşağıdaki gibi sıralanabilir:

a. Tüm kararlar tek merkezden alındığından ve kararların uygulanması aynı merkezce denetlendiğinden, aynı hizmetlerle ilgili tüm gelir ve giderler gene aynı merkezce değerlendirilir; bu da ülkede birlik ve beraberliğin sağlanmasına katkıda bulunabilir.

b. Tüm ülke düzeyine yayılmış olan askeri güçler üzerindeki sivil yönetimin üstünlüğü, idarenin tek merkezde toplanmasıyla daha kolay sağlanabilir.

c. İdarenin ve kamu görevlilerinin tarafsızlığı yerel etkilerden uzak olmaları nedeniyle daha kolay sağlanır.

d. Özellikle bölgeler arasında gelişme farklılıkları olan ülkelerde kaynakların tüm ülke düzeyine dengeli dağılımı daha kolay sağlanır.

e. Uzman personelin ülke düzeyine dengeli dağılımı merkezi planlama ile daha kolay sağlanır (Günal, 2010).

Her yönetim biçiminin olduğu gibi merkezi yönetimin de yararları olduğu gibi sakıncaları da vardır: Merkezden yönetim her şeyden önce kırtasiyeciliği (bürokratizm) artırır. Merkezden yönetim katılımcı ve çoğulcu yönetim anlayışına kısaca demokrasi ilkesine uygun değildir. Merkezde görevli ve yetkili siyasi kadrolar, toplumun gelirlerini dağıtırken; ülke kalkınmasını tüm bölgeler için dengeleyecekleri yerde kendi bölgelerine ayrıcalık sağlayabilirler. Taşrada görevli kamu görevlileri, kamu hizmeti sunarken yerel halkın özelliklerini, ihtiyaçlarını ve bölgenin durumunu göz önüne alacakları yerde; sürekli merkezin kararlarını, verilen emir ve talimatları uygulamak durumunda olabilirler. Merkezi yönetim tüm ülkeyi ve toplumu kontrol edip, yönetebilmek için oldukça güçlü olmak isteyecek; çok sayıda kamu görevlisi, uzman personel, çok gelişmiş araç ve gereçlere ihtiyaç duyacak bu da kamu harcamalarını artıracaktır (Günal, 2010).

Yerinden yönetim anlayışı, siyasi, ekonomik ve eğitsel açılardan yaklaşıldığında genel olarak katılım, firsat eşitliği, reform gibi kavramlarla birlikte kullanılan ve merkezi olmayan, bağlama göre yerel politikalar geliştirilmesi esasına dayanan bir yönetim anlayışını ifade etmektedir (Şişman \& Turan, 2003). Hizmetlerin yürütüldüğü ya da işlerin yapıldığ1 yerde yönetilmesi anlamına gelen yerinden yönetim anlayışı, kamu yönetimi disiplininde merkezi yönetimin elindeki planlama, karar verme, kamu gelirlerini toplama gibi işlevlerin bir kısmını taşra kuruluşlarına, yerel yönetimlere, yarı özerk kamu kurumlarına, meslek kuruluşlarına ve (ya) yönetimin dışındaki gönüllü örgütlere aktarılması olarak ifade edilebilir (Erençin \& Yolcu, 2008).

Yerinden yönetim, kamu yönetiminde yerelle ilgili, uygulamaya dönük, karar alma yetki ve sorumluluğunun taşra ve yurt dışı birimlerine aktarılmasını ifade eder. Yerinden yönetim anlayışındaki temel yaklaşım, ülke genelindeki hizmetlerin daha hızlı ve daha akıcı bir biçimde yerine getirilmesini sağlamak inancıdır (Taşar, 2009). Bu çerçevede yetki genişliği, yetki devri, hizmette yerellik ve özelleştirme gibi kavramlar yerinden yönetim tekniği içinde değerlendirilmektedir (Erençin \& Yolcu, 2008). 
Yerinden yönetim örgütleri devlete nazaran daha sınırlı bir alan üzerinde hizmet verirler ve devletin kontrolü altında bulunurlar. Yerel yerinden yönetim örgütlerinin yetkileri, yapıları ve kurumları ile çalışanlarının atanma yöntemleri devlet tarafından uygulanmaktadır (Arslan, 2013).

Yerinden yönetim yaklaşımının dezavantajları (Usluel, 1995), tek bir politika izlenmesinin güçlüğü, eşgüdümlenmede güçlük, yetki kaybı, hizmet kalitesinin ülke geneline yayılamaması, mali dengede bozukluk olarak özetlenebilir. Devlet gerekli kaynak ve teknik yardım sağlayarak bu tür eşitsizlikleri telafi etmezse, o zaman âdemi merkeziyetçilik ciddi eşitsizliklere yol açabilir (Welsch \& McGinn, 1999).

Yerelleşme ayrıca, çelişen kararlar veya işlevleri yürütme başarısızlıklarına neden olarak eğitim yönetimi üzerinde kalite ve verimlilik konusunda olumsuz etkileri ile de karışıklığa yol açabilir (Winkler \& Yeo, 2007).

2012 y1lında düzenlenen OECD Eğitimde Etkili Yerel Yönetim Konferansında Busemeyer (2012), yerinden yönetimin dezavantajlarını şu şekilde sıralamıştır: Daha az değil, ama daha çok bürokrasi; yerel kurumlarında özel çıkarlar tarafından ele geçirilebilme ihtimali; yerel düzeyde idari "aşırı yüklenme"; rekabetin, maliyetler açısından zararlı sonuçlar doğurabilmesi; performans standartları uzak ulusal düzeyde ayarlandığında sistemin "Oyun"u; eğitim performansları üzerindeki etkisinin belirsizliği; negatif dişsallıklar: artan tabakalaşma.

Sonuç olarak, yerelleşmenin, etkinliği, açıklığ 1 , hesap verebilirliği ve sorumluluğu arttıran teorik avantajları, literatürde açık olmakla birlikte, özellikle bu konuda uygulamada ciddi sorunlarla karşılaşılmaktadır. Ciddi finansal kısıtlar altında bulunan ülkelerde, bu sorunlar daha derin hissedilmektedir (Özgen, 2011).

Merkezden ve yerinden yönetimin verilen hizmetlerde ülke şartlarına göre bir dengelemenin daha uygun olacağı düşüncesi bilimsel platformda ağır basmaktadır. Bu noktada eğitimde hangi yetkilerin yerel yönetimlere devredilmesi, hangilerinin merkezde kalması ve yerel düzeyde nasıl bir örgütlenme olması gerektiği konusunda tartışmalar sürmektedir (Türkoğlu, 2004).Okul merkezli yönetim, eğitim-öğretimi geliştirmek amacıyla okul düzeyindeki yetki ve sorumlulukların artırılmasına, özerklik ve katılımlı karar almaya dayalı okulların karar alma birimi olarak kabul eden eğitimin yerinden yönetim biçimidir (Özgen, 2011). 
Tablo 1

Eğitim Açısından Merkezden ve Yerinden Yönetim Karşılaştırılması

\begin{tabular}{|c|c|}
\hline Merkeziyetçi Yönetim & Yerinden Yönetim \\
\hline $\begin{array}{l}\text { Şitim programları, ülkenin bütününde standarttır. } \\
\text { lkenin özellik ve gereksinimleri ön plandadır. }\end{array}$ & $\begin{array}{l}\text { Okulun eğitim programı, yerel gereksinim } \\
\text { özelliklere uygun olarak geliştirilebilir. }\end{array}$ \\
\hline $\begin{array}{l}\text { Okulların eğitiminin nitelikçe daha eşit olmasını } \\
\text { ve böylece eğitimde firsat ve olanak eşitliğini } \\
\text { sağlamak daha kolaydır. }\end{array}$ & $\begin{array}{l}\text { Eğitim kurumları arasında gerek ülke bazında } \\
\text { gerekse yerel birim bazında bir eşitlik yerine } \\
\text { rekabet ve yarış vardır. }\end{array}$ \\
\hline $\begin{array}{l}\text { Eğitim toplumdaki egemen güçlerin olumsuz } \\
\text { etkisinden kurtarılabilir. }\end{array}$ & $\begin{array}{l}\text { Bu etkiler, olumlu da olabilir. Bu da yerel birimde } \\
\text { başarıy getirir. }\end{array}$ \\
\hline $\begin{array}{l}\text { Eğitimi ülke düzeyinde planlamak daha kolaydır } \\
\text { ve planlar daha başarılı olabilir. }\end{array}$ & a yerel düzeyde olmaktadır. \\
\hline $\begin{array}{l}\text { Eğitimde finansman ve insan kaynakları açısından } \\
\text { savurganlık engellenmiş ve daha dengeli ve akılcı } \\
\text { kaynak dağılımı sağlanır.. }\end{array}$ & $\begin{array}{l}\text { Eğitimin finanse edilmesinde ve insan gücü } \\
\text { gereksinimlerinin sağlanmasında yerel olanakların } \\
\text { sağlanması daha kolaydır. Ancak ülke genelinde } \\
\text { rasyonel dağılım oluşmayabilir }\end{array}$ \\
\hline $\begin{array}{l}\text { Yerel insan kaynaklarından merkezde } \\
\text { yararlanmak zordur. }\end{array}$ & $\begin{array}{l}\text { Yerel düzeyde nitelikli insan gücünden } \\
\text { yararlanmada yerel olanakların sağlanması daha } \\
\text { kolaydır. }\end{array}$ \\
\hline $\begin{array}{l}\text { Eğitim personelinin iş güvencelerini sağlamak } \\
\text { daha kolay görülmektedir. }\end{array}$ & $\begin{array}{l}\text { İş güvencesi, yarışmacı özellik nedeniyle daha } \\
\text { düşüktür. }\end{array}$ \\
\hline $\begin{array}{l}\text { Personel ücret ve yükselmeleri daha dengeli } \\
\text { olabilmektedir. }\end{array}$ & $\mathrm{Pe}$ \\
\hline $\begin{array}{l}\text { Nitelikli personelin merkezde } \\
\text { edilmesiyle taşrada nitelikli personel istihdam } \\
\text { gereksizleşir ve dolayısıyla personel giderleri } \\
\text { azalır. }\end{array}$ & $\begin{array}{l}\text { Özellikle uzman düzeyinde eleman istihdamı, } \\
\text { bunların temini zor olduğu için personel giderleri } \\
\text { artar. }\end{array}$ \\
\hline $\begin{array}{l}\text { Sorunlara dişarıdan ve daha yansız, nesnel olarak } \\
\text { bakmak mümkündür. }\end{array}$ & $\begin{array}{l}\text { Sorunların yerel örgütler ve yöneticilerce } \\
\text { paylaşılmasını ve böylelikle çözümünü } \\
\text { kolaylaştırır. }\end{array}$ \\
\hline $\begin{array}{l}\text { Merkezden kararlar genel olarak eksik bilgi ile } \\
\text { verilir. }\end{array}$ & $\begin{array}{l}\text { Yerel yönetim anlayışı aşııı büyüyerek hantallaşan } \\
\text { merkez yönetimin işini kolaylaştırır. Yapıyı } \\
\text { dinamikleştirir. }\end{array}$ \\
\hline $\begin{array}{l}\text { Okul bina, araç-gereç ve donanımlar konularında } \\
\text { standartlar geliştirmek daha kolaydır. }\end{array}$ & $\begin{array}{l}\text { Yerel özelliklere uygun bina ve donanım sağlama } \\
\text { olanağı daha fazladır. }\end{array}$ \\
\hline $\begin{array}{l}\text { Okul-aile işbirliğini sağlamak daha zor } \\
\text { olabilmektedir. }\end{array}$ & $\begin{array}{l}\text { Okul-aile işbirliğini sağlamada daha yüksek başarı } \\
\text { elde edilebilmektedir. }\end{array}$ \\
\hline 年 & \\
\hline
\end{tabular}

Kaynak: Arslan, 2013.

\section{Yönetim Çeşitleri ve Yerinden Yönetimle İlgili Yapılan Çalışmalar}

Merkeziyetçi Yönetim ve Yerinden Yönetim ve Okula Dayalı Yönetimle İlgili Yapılan çalışmalar genel olarak değerlendirildiğinde bu konularda yapılmış çok çalışmaya rastlanılmamaktadır. Bu konularda yapılan çalışmalardan biri, Yalçınkaya'nın 
(2004) 'Okul Merkezli Yönetim’ isimli betimsel çalışmasıdır. Çalışma sonuçlarına göre müdür yardımcıları yönetici adaylarının, öğretmen yönetici adaylarına göre okul merkezli yönetim modelini daha yüksek oranda benimsedikleri tespit edilmiştir. Bunun yanında her iki grubun da okul merkezli yönetim modeline ilişkin olumlu görüş belirtmeleri onların bu modeli merkeziyetçi modele alternatif bir model olarak algıladıklarını göstermektedir.

Turan, Yücel, Karataş ve Demirhan (2010) tarafindan yapılan 'Okul Müdürlerinin Yerinden Yönetim Hakkındaki Görüşleri’ konulu çalışma bulgularına göre 'Yönetim' boyutu altı alt başlikta incelenmiştir. $\mathrm{Bu}$ boyut bütünsel incelendiğinde; okul müdürlerinin bu kategorideki konularda karar mercii olarak uygun gördükleri birimlerden en yüksek frekansın Bakanlık birimine ait olduğu görülmektedir. 'Okulun Örgütlenmesi' boyutu dokuz alt başlıkta incelenmiştir. Bu boyut bütünsel incelendiğinde yüksek frekansın Okul birimine ait olduğu görülmektedir. ‘İnsan Kaynakları Yönetimi’ boyutu on iki alt başlıkta incelenmiştir. Bu kategoride en yüksek frekansın Okul birimine ait olduğu görülmektedir. 'Eğitim Programı ve Öğretimi” boyutu on dört alt başlikta incelenmiştir. $\mathrm{Bu}$ kategoride en yüksek frekansın Bakanlık birimine ait olduğu görülmektedir. Bu dağılımı, Okul ve İl birimleri takip etmektedir. 'Ölçme Değerlendirme Boyutu' sekiz alt başlıkta incelenmiştir. Bu kategori bütünsel incelendiğinde; okul müdürlerinin bu kategorideki konularda karar mercii olarak uygun gördükleri birimlerden en yüksek frekansın İl birimine ait olduğu görülmektedir.

Yavuz'un (2015) 'Lise Yönetici ve Öğretmenlerinin Yerinden ve Merkezden Yönetim Yönelimlerinin Karar Verme Sürecine Etkileri’ adlı çalışmasına göre lise yöneticileri ve öğretmenleri okulda yerinden yönetim yaklaşımını Çok düzeyinde önemsemektedirler.

Ölmez ve Tonbul (2011) tarafindan 'Eğitim Yönetiminin Yerelleşmesi Sürecinde Bir Uygulama: Eğitim Bölgeleri Danışma Kurulları' isimli çalışma yapılmıştır. Çalışmanın bulguları, Eğitim Bölgeleri Danışma Kurulları Yönergesinin amaçlarından biri olan eğitim yönetiminin yerel yönetimlere aktarılması hedefi dikkate alındığında bu uygulamaya henüz hazır olunmadığını ve hedeflenen ilkelerin hayata geçirilemediğini, okulun iç ve dış paydaşları arasındaki etkileşimin yetersiz olduğunu, eğitim bölgeleri danışma kurullarının yeniden yapılandırılması gerektiğini ortaya koymaktadır.

Ortaç (2003) tarafından 'İlköğretim kurumlarındaki yönetici yardımcılarının yetki devri ile ilgili görüş ve beklentileri’ adlı bir çalışma yapılmıştır. Yönetici yardımcılarının yetki devrine ait görüşleri tespit edilmeye çalışılmış; çalışma verilerinin çözümlenmesinden yetkisiz oldukları görülmüştür. Yönetici yardımcılarının yetki devri ile ilgili beklentilerinin az yetkili olma yönünde çıkması düşündürücü olmuştur. Beklentiler ile görüşlerin karşılaştırılması sonucunda, anlamlı farklılıklar gözlenmiş, yönetici yardımcılarının çok yetkili olmak yerine yetkilerde paylaşımcı olmayı istedikleri sonucuna varılmıştır.

Ekşi ve Kaya'nın (2011) yaptı̆̆ 'Okul Merkezli Yönetim Sistemine İlişkin Öğretmen Görüşleri’ başlıklı çalışmada öğretmenlerin okul merkezli yönetim (OMY) sistemine ilişkin görüşlerinin betimlemesi amaçlanmıştır. İstatistiksel analizler 
neticesinde elde edilen bulgular doğrultusunda öğretmenlerin OMY sistemlerine ilişkin grup içi katılımların yüksek olduğu ve okul merkezli yönetim (OMY) sistemine ilişkin görüşlerinin, iş gören olarak hizmet verdikleri okulun finansman türüne, aldıkları ödül sayılarına göre farklılaştığı sonucuna ulaşılmıştır. Çalışma örneklemin oluşturan öğretmenlerin çalıştıkları okulun finans türüne göre özel finanslı ilköğretim okullarında çalışan öğretmenlerin $x=223.61$ (yüksek), devlet finanslı ilköğretim okullarında $x=189.27$ (yüksek)tir.

\section{Yöntem}

$\mathrm{Bu}$ çalışma eğitimde yerinden yönetime ilişkin okul yöneticilerinin görüşlerinin tespit edilmesi amaçlandığından çalışma nicel çalışma yöntemlerinden betimsel tarama deseninde kurgulanmıştır. Tarama modelleri, geçmişte ya da halen var olan bir durumu var olduğu sekliyle betimlemeyi amaçlayan çalışma yaklaşımlarıdır. Araştırmaya konu olan olay, birey ya da nesne kendi koşulları içinde ve olduğu gibi tanımlanmaya çalışılır. Onları herhangi bir şekilde değiştirme etkileme çabası gösterilmez. Bilinmek istenen şey vardır ve oradadır. Önemli olan onu uygun bir biçimde gözleyip belirleyebilmektir. (Karasar, 2005).

\section{Evren ve Örneklem}

Çalışmanın evrenini Antalya il merkezi eğitim kurumlarında görev yapan toplam 423 okul müdürü oluşturmaktadır. Örneklemi ise basit tesadüfî örnekleme yoluyla seçilen, yeni-yeniden ataması yapılan 151 (\%35) ilkokul, ortaokul ve lise okul müdürleri oluşturmaktadır. Örneklem Antalya merkez ilçelerindeki (Kepez, Muratpaşa, Konyaaltı) ilkokul, ortaokul ve liseler olmak üzere toplam 151 okuldan alınmıştır. Örneklem büyüklüğünün belirlenmesinde, Krejcie ve Morgan (1970) tarafından önerilen çizelgeden yararlanılmış, anket 250 kişiye uygulanmıştır. Ancak bütün anketlerin geri dönüşümünün olmaması ve anketlerin eksik ve hatalı doldurulması nedeniyle geçerli olan 151 anket değerlendirmeye alınmıştır. Örnekleme İl Milli Eğitim Müdürlüğü tarafından gerçekleştirilen yeni atanan okul yöneticilerinin uyum eğitimi sürecinde ulaşılmıştır.

\section{Veri Toplama Aracı Ve Verilerin Çözümlenmesi}

Çalışmanın verileri, Çınkır (2010) tarafından "Eğitimin Yerinden Yönetimi Ölçeği” aracı ile toplanmıştır. Ölçekte, altı karar kategorisi ve bu kategorilerde yer bulan alt kararlar tercihleri yer almaktadır. Bu altı kategoriyi; yönetim, okulun örgütlenmesi, insan kaynakları yönetimi, eğitim programı ve öğretimi, ölçme değerlendirme, eğitim finansmanı oluşturmaktadır.

Okul müdürlerinden bu kararların alınma yerleri olarak hangi birimin olmas1 gerektiği ile ilgili görüşlerini belirtmeleri istenmektedir. Bu kararların alınma yerleri olarak ankette; bakanlık, bölge, il, ilçe, belediye, okul gibi birimler seçenek olarak sunulmuştur. Verilerin çözümlenmesinde SPSS paket programından yararlanılarak yüzde ve frekans hesaplamaları yapılmıştır. Okul yöneticilerinin yerinden yönetim hakkındaki görüşleri ile kıdem arasındaki ilişkiyi görmek için kay kare analizinden yararlanılmıştır. Anlamlılık düzeyi .05 olarak alınmıştır. Yapılan yüzde ve frekans hesaplamalarının 
amacı; öncelikle grup başlıkları için uygun görülen karar düzeyleri hakkında bilgi almak, daha sonra da gruplara ait tüm yönergelerin ve karar konularının tek tek hangi karar düzeyinde ele alınmasının gerektiğini ortaya çıkarmaktır. Yapılan kay kare analizinin amacı ise; iki sınıflamalı (kategorik) değişken arasında anlamlı bir ilişki olup olmadığını ortaya çıkarmaktır (Büyüköztürk, 2014).

\section{Bulgular}

Eğitimin yerinden yönetimi konusunda eğitim kurumlarına yeniden atanan okul yöneticilerinin yerinden yönetim anlayışına ilişkin görüşlerini tespit etmek amaciyla yapılan bu çalışmada yapılan istatistiksel analizler sonucunda aşağıdaki bulgular tespit edilmiştir. Analizlerde ise okul müdürlerinin 6 kategori ve her konu başlığı için önerdikleri birimlerin frekansları hesaplanarak yapılmıştır. Yapılan analiz sonucunda elde edilen bulgular şu şekildedir.

\section{Tablo 2}

Okul Müdürlerinin Yönetim Boyutuyla İlgili Alınacak Kararlarda Karar Mercileri Hakkındaki Görüşleri

\begin{tabular}{lccccccc}
\hline Yönetim & & Bakanlik & Bölge & İl & İlçe & Belediye & Okul \\
\hline Politikaların Belirlenmesi & $\mathrm{f}$ & 100 & 19 & 21 & 1 & 2 & 8 \\
& $\%$ & 66.2 & 12.6 & 13.9 & 0.7 & 1.3 & 5.3 \\
\hline Planların Yapılması & $\mathrm{f}$ & 50 & 43 & 38 & 6 & 1 & 13 \\
& $\%$ & 33.1 & 28.5 & 25.2 & 4 & 0.7 & 8.6 \\
\hline Örgütlenme & $\mathrm{f}$ & 87 & 26 & 27 & 7 & 1 & 3 \\
& $\%$ & 57.6 & 17.2 & 17.9 & 4.6 & 0.7 & 2 \\
\hline Politikaların Uygulanması & $\mathrm{f}$ & 63 & 20 & 36 & 11 & 5 & 16 \\
& $\%$ & 41.7 & 13.2 & 23.8 & 7.3 & 3.3 & 10.6 \\
\hline Planların Uygulanması & $\mathrm{f}$ & 39 & 12 & 55 & 10 & 2 & 33 \\
& $\%$ & 25.8 & 7.9 & 36.4 & 6.6 & 1.3 & 21.9 \\
\hline Gereksinimlere göre eğitim & $\mathrm{f}$ & 48 & 20 & 42 & 12 & 8 & 21 \\
hizmeti sunmak & $\%$ & 31.8 & 13.2 & 27.8 & 7.9 & 5.3 & 13.9 \\
\hline Toplam & & 387 & 140 & 219 & 47 & 19 & 98 \\
\hline
\end{tabular}

Yönetim boyutu altı alt başlıkta incelenmiştir. Bu boyuta bütünsel olarak bakıldığında; okul müdürlerinin bu boyutla ilgili alınacak kararlarda karar mercii olarak uygun gördükleri en yüksek frekansa sahip birimin Bakanlık (\%42.7) olduğu görülmektedir. Bu dağılımı sırasıyla il (\%24.1) ve bölge (\%15.4) takip etmektedir. En düşük frekansın belediyeye (\%2.09) ait olduğu görülmektedir. 
Tablo 3

Okul Müdürlerinin Okulun Örgütlenmesi Boyutuyla İlgili Alınacak Kararlarda Karar Mercileri Hakkındaki Görüşleri

\begin{tabular}{|c|c|c|c|c|c|c|c|}
\hline Okulun Örgütlenmesi & & Bakanlık & Bölge & İl & İlçe & Belediye & Okul \\
\hline \multirow{2}{*}{$\begin{array}{l}\text { Okul takviminin } \\
\text { belirlenmesi }\end{array}$} & $\mathrm{f}$ & 61 & 33 & 41 & 7 & 3 & 6 \\
\hline & $\%$ & 40.4 & 21.9 & 27.2 & 4.6 & 2 & 4 \\
\hline \multirow[t]{2}{*}{ Okulların yapılandırılması } & $\mathrm{f}$ & 36 & 15 & 49 & 20 & 4 & 27 \\
\hline & $\%$ & 23.8 & 9.9 & 32.5 & 13.2 & 2.6 & 17.9 \\
\hline \multirow{2}{*}{$\begin{array}{l}\text { Vizyon. amaçların } \\
\text { belirlenmesi }\end{array}$} & $\mathrm{f}$ & 10 & 6 & 19 & 15 & 4 & 97 \\
\hline & $\%$ & 6.6 & 4 & 12.6 & 9.9 & 2.6 & 64.2 \\
\hline \multirow{2}{*}{$\begin{array}{l}\text { Alt düzeydeki koşulların } \\
\text { belirlenmesi }\end{array}$} & $\mathrm{f}$ & 23 & 11 & 22 & 20 & 6 & 69 \\
\hline & $\%$ & 15.2 & 7.3 & 14.6 & 13.2 & 4 & 45.7 \\
\hline \multirow{2}{*}{$\begin{array}{l}\text { Eğitim. öğretim sürelerinin } \\
\text { belirlenmesi }\end{array}$} & $\mathrm{f}$ & 46 & 11 & 44 & 18 & 2 & 30 \\
\hline & $\%$ & 30.5 & 7.3 & 29.1 & 11.9 & 1.3 & 19.9 \\
\hline \multirow{2}{*}{$\begin{array}{l}\text { Çalışma koşullarının } \\
\text { belirlenmesi }\end{array}$} & $\mathrm{f}$ & 57 & 15 & 32 & 14 & 8 & 25 \\
\hline & $\%$ & 37.7 & 9.9 & 21.2 & 9.3 & 5.3 & 16.6 \\
\hline \multirow{2}{*}{$\begin{array}{l}\text { Kültürel ilişkilerin } \\
\text { koordine edilmesi }\end{array}$} & $\mathrm{f}$ & 95 & 5 & 26 & 6 & 10 & 9 \\
\hline & $\%$ & 62.9 & 3.3 & 17.2 & 4 & 6.6 & 6 \\
\hline \multirow{2}{*}{$\begin{array}{l}\text { Okul takvimini } \\
\text { gereksinimlere göre } \\
\text { ayarlama }\end{array}$} & $\mathrm{f}$ & 16 & 31 & 20 & 47 & 15 & 22 \\
\hline & $\%$ & 10.6 & 20.5 & 13.2 & 31.1 & 9.9 & 14.6 \\
\hline \multirow{2}{*}{$\begin{array}{l}\text { Okul gelişim planları } \\
\text { hazırlama }\end{array}$} & $\mathrm{f}$ & 8 & 5 & 19 & 13 & 4 & 102 \\
\hline & $\%$ & 5.3 & 3.3 & 12.6 & 8.6 & 2.6 & 67.5 \\
\hline Toplam & & 352 & 132 & 272 & 160 & 56 & 387 \\
\hline
\end{tabular}

Okulun Örgütlenmesi boyutu dokuz alt başl1kta incelenmiştir. Bu boyuta bütünsel olarak bakıldığında; okul müdürlerinin bu boyutla ilgili alınacak kararlarda karar mercii olarak uygun gördükleri en yüksek frekansa sahip birimin Okul (\%28.4) olduğu görülmektedir. Bu dağılımı sırasıyla, Bakanlık (\%25.9) ve İl (\%20) takip etmektedir. En düşük frekansın Belediye'ye (\%4.12) ait olduğu görülmektedir. 
Tablo 4

Okul Müdürlerinin İnsan Kaynakları Yönetimi Boyutuyla İlgili Alınacak Kararlarda Karar Mercileri Hakkındaki Görüşleri

\begin{tabular}{|c|c|c|c|c|c|c|c|}
\hline İnsan Kaynakları Yönetim & & Bakanlık & Bölge & İl & İlçe & Belediye & Okul \\
\hline \multirow{2}{*}{$\begin{array}{l}\text { Personeli işe alma. işten } \\
\text { çıarma }\end{array}$} & $\mathrm{f}$ & 61 & 6 & 25 & 13 & 7 & 39 \\
\hline & $\%$ & 40.4 & 4 & 16.6 & 8.6 & 4.6 & 25.8 \\
\hline \multirow{2}{*}{$\begin{array}{l}\text { İşgörenlere Ödenecek } \\
\text { ücretlerin } \\
\text { kararlaştırılması }\end{array}$} & $\mathrm{f}$ & 73 & 9 & 27 & 10 & 8 & 24 \\
\hline & $\%$ & 48.3 & 6 & 17.9 & 6.6 & 5.3 & 15.9 \\
\hline \multirow{2}{*}{$\begin{array}{l}\text { Hizmet öncesi öğretmen } \\
\text { eğitimi hizmetlerin } \\
\text { sağlanması }\end{array}$} & $\mathrm{f}$ & 63 & 9 & 47 & 14 & 4 & 14 \\
\hline & $\%$ & 41.7 & 6 & 31.1 & 9.3 & 2.6 & 9.3 \\
\hline \multirow{2}{*}{$\begin{array}{l}\text { Hizmetiçi eğitim } \\
\text { programı düzenleme. } \\
\text { katılımı sağlama }\end{array}$} & $\mathrm{f}$ & 46 & 15 & 46 & 23 & 5 & 16 \\
\hline & $\%$ & 30.5 & 9.9 & 30.5 & 15.2 & 3.3 & 10.6 \\
\hline \multirow{2}{*}{$\begin{array}{l}\text { Öğretmenlik yeterlik } \\
\text { belgesinin verilmesi }\end{array}$} & $\mathrm{f}$ & 78 & 6 & 26 & 12 & 3 & 26 \\
\hline & $\%$ & 51.7 & 4 & 17.2 & 7.9 & 2 & 17.2 \\
\hline \multirow[t]{2}{*}{ Personel özlük hakları } & $\mathrm{f}$ & 50 & 6 & 37 & 29 & 4 & 25 \\
\hline & $\%$ & 33.1 & 4 & 24.5 & 19.2 & 2.6 & 16.6 \\
\hline \multirow{2}{*}{$\begin{array}{l}\text { Performans yönetimi ve } \\
\text { değerlendirme }\end{array}$} & $\mathrm{f}$ & 21 & 4 & 31 & 26 & 4 & 65 \\
\hline & $\%$ & 13.9 & 2.6 & 20.5 & 17.2 & 2.6 & 43 \\
\hline \multirow{2}{*}{$\begin{array}{l}\text { Disiplin ilke ve } \\
\text { yöntemlerinin } \\
\text { belirlenmesi }\end{array}$} & $\mathrm{f}$ & 72 & 4 & 33 & 23 & 2 & 17 \\
\hline & $\%$ & 47.7 & 2.6 & 21.9 & 15.2 & 1.3 & 11.3 \\
\hline \multirow{2}{*}{$\begin{array}{l}\text { Disiplin ilke ve } \\
\text { yöntemlerinin } \\
\text { uygulanması }\end{array}$} & $\mathrm{f}$ & 39 & 3 & 36 & 23 & 4 & 46 \\
\hline & $\%$ & 25.8 & 2 & 23.8 & 15.2 & 2.6 & 30.5 \\
\hline \multirow{2}{*}{$\begin{array}{l}\text { Okulun denetim ve } \\
\text { değerlendirilmesi }\end{array}$} & $\mathrm{f}$ & 17 & 7 & 52 & 51 & 5 & 19 \\
\hline & $\%$ & 11.3 & 4.6 & 34.4 & 33.8 & 3.3 & 12.6 \\
\hline \multirow{2}{*}{$\begin{array}{l}\text { Öğretmenlerin denetim } \\
\text { ve değerlendirilmesi }\end{array}$} & $\mathrm{f}$ & 13 & 6 & 28 & 26 & 3 & 75 \\
\hline & $\%$ & 8.6 & 4 & 18.5 & 17.2 & 2 & 49.7 \\
\hline \multirow{2}{*}{$\begin{array}{l}\text { Çalışma geliştirme } \\
\text { çalışmaları }\end{array}$} & $\mathrm{f}$ & 32 & 12 & 47 & 19 & 4 & 37 \\
\hline & $\%$ & 21.2 & 7.9 & 31.1 & 12.6 & 2.6 & 24.5 \\
\hline Toplam & & 565 & 87 & 435 & 269 & 53 & 403 \\
\hline
\end{tabular}

İnsan Kaynakları Yönetimi boyutu on iki alt başlıkta incelenmiştir. Bu boyuta bütünsel olarak bakıldığında; okul müdürlerinin bu boyutla ilgili alınacak kararlarda karar mercii olarak uygun gördükleri en yüksek frekansa sahip birimin Bakanlık (\%31.1) 
olduğu görülmektedir. Bu dağılımı sırasıyla, İl (\%24) ve Okul (\%22.24) takip etmektedir. En düşük frekansın Belediye’ye (\%2.92) ait olduğu görülmektedir.

Tablo 5

Okul Müdürlerinin Ĕgitim Programı ve Öğretimi Boyutuyla İlgili Alınacak Kararlarda Karar Mercileri Hakkındaki Görüşleri

\begin{tabular}{|c|c|c|c|c|c|c|c|}
\hline \multicolumn{2}{|l|}{ Eğitim Programı ve Öğretimi } & Bakanlık & Bölge & İl & İlçe & Belediye & Okul \\
\hline \multirow{2}{*}{$\begin{array}{l}\text { Eğitim programının } \\
\text { içeriğinin belirlenmesi }\end{array}$} & $\mathrm{f}$ & 89 & 16 & 26 & 7 & 1 & 12 \\
\hline & $\%$ & 58.9 & 10.6 & 17.2 & 4.6 & 0.7 & 7.9 \\
\hline \multirow[t]{2}{*}{ Derslerin belirlenmesi } & $\mathrm{f}$ & 77 & 15 & 28 & 9 & 3 & 19 \\
\hline & $\%$ & 51 & 9.9 & 18.5 & 6 & 2 & 12.6 \\
\hline \multirow[t]{2}{*}{ Temel dersler } & $\mathrm{f}$ & 90 & 7 & 28 & 6 & 3 & 17 \\
\hline & $\%$ & 59.6 & 4.6 & 18.5 & 4 & 2 & 11.3 \\
\hline \multirow[t]{2}{*}{ Yardımcı dersler } & $\mathrm{f}$ & 36 & 26 & 34 & 21 & 7 & 27 \\
\hline & $\%$ & 23.8 & 17.2 & 22.5 & 13.9 & 4.6 & 17.9 \\
\hline \multirow{2}{*}{$\begin{array}{l}\text { Derslerin içeriğinin } \\
\text { belirlenmesi }\end{array}$} & $\mathrm{f}$ & 88 & 18 & 23 & 7 & 2 & 13 \\
\hline & $\%$ & 58.3 & 11.9 & 15.2 & 4.6 & 1.3 & 8.6 \\
\hline \multirow{2}{*}{$\begin{array}{l}\text { Ders kitaplarının } \\
\text { belirlenmesi ve seçimi }\end{array}$} & $\mathrm{f}$ & 73 & 14 & 31 & 6 & 1 & 26 \\
\hline & $\%$ & 48.3 & 9.3 & 20.5 & 4 & 0.7 & 17.2 \\
\hline \multirow{2}{*}{$\begin{array}{l}\text { Ders kitaplarının yazımı. } \\
\text { basımı. güncelleştirilmesi }\end{array}$} & $\mathrm{f}$ & 108 & 11 & 24 & 2 & 1 & 5 \\
\hline & $\%$ & 71.5 & 7.3 & 15.9 & 1.3 & 0.7 & 3.3 \\
\hline \multirow{2}{*}{$\begin{array}{l}\text { Ders kitaplarının ücretsiz } \\
\text { sağlanması }\end{array}$} & f & 114 & 5 & 17 & 3 & 5 & 7 \\
\hline & $\%$ & 75.5 & 3.3 & 11.3 & 2 & 3.3 & 4.6 \\
\hline \multirow{2}{*}{$\begin{array}{l}\text { Okutulacak diğer } \\
\text { kitaplara onay verme }\end{array}$} & $\mathrm{f}$ & 46 & 10 & 36 & 27 & 4 & 28 \\
\hline & $\%$ & 30.5 & 6.6 & 23.8 & 17.9 & 2.6 & 18.5 \\
\hline \multirow{2}{*}{$\begin{array}{l}\text { Materyallerin kullanımı } \\
\text { ile ilgili talimatların } \\
\text { hazırlanması }\end{array}$} & $\mathrm{f}$ & 63 & 14 & 32 & 13 & 4 & 25 \\
\hline & $\%$ & 41.7 & 9.3 & 21.2 & 8.6 & 2.6 & 16.6 \\
\hline \multirow{2}{*}{$\begin{array}{l}\text { Özel okulların pedagojik } \\
\text { şartlarının düzenlenmesi }\end{array}$} & $\mathrm{f}$ & 93 & 12 & 24 & 9 & 3 & 10 \\
\hline & $\%$ & 61.6 & 7.9 & 15.9 & 6 & 2 & 6.6 \\
\hline \multirow{2}{*}{$\begin{array}{l}\text { Kültürel etkinliklere } \\
\text { dönük eğitim hizmeti } \\
\text { sunmak }\end{array}$} & $\mathrm{f}$ & 46 & 12 & 36 & 21 & 13 & 23 \\
\hline & $\%$ & 30.5 & 7.9 & 23.8 & 13.9 & 8.6 & 15.2 \\
\hline \multirow{3}{*}{$\begin{array}{l}\text { Ö ğretim yöntem ve } \\
\text { tekniklerin belirlenmesi }\end{array}$} & $\mathrm{f}$ & 69 & 9 & 24 & 6 & 5 & 38 \\
\hline & $\%$ & 45.7 & 6 & 15.9 & 4 & 3.3 & 25.2 \\
\hline & $\mathrm{f}$ & 77 & 9 & 30 & 5 & 3 & 27 \\
\hline
\end{tabular}




\begin{tabular}{|c|c|c|c|c|c|c|}
\hline $\begin{array}{l}\text { Ders programlarının } \\
\text { hazırlanması. } \\
\text { geliştirilmesi }\end{array}$ & $\%$ & 6 & 19.9 & 3.3 & 2 & 17.9 \\
\hline Toplam & 1069 & 178 & 393 & 142 & 55 & 277 \\
\hline
\end{tabular}

Eğitim Programı ve Öğretimi boyutu on dört alt başlıkta incelenmiştir. Bu boyuta bütünsel olarak bakıldığında; okul müdürlerinin bu boyutla ilgili alınacak kararlarda karar mercii olarak uygun gördükleri en yüksek frekansa sahip birimin Bakanlık (\%50.5) olduğu görülmektedir. Bu dağılımı sırasıyla, İl (\%18.5) ve Okul (\%13.1) takip etmektedir. En düşük frekansın Belediye'ye (\%2.6) ait olduğu görülmektedir.

Tablo 6

Okul Müdürlerinin Ölçme Değerlendirme Boyutuyla İlgili Alınacak Kararlarda Karar Mercileri Hakkındaki Görüşleri

\begin{tabular}{|c|c|c|c|c|c|c|c|}
\hline Ölçme Değerlendirme & & Bakanlık & Bölge & İl & İlçe & Belediye & Okul \\
\hline \multirow{2}{*}{$\begin{array}{l}\text { Öğretmen } \\
\text { yeterliklerinin } \\
\text { belirlenmesi }\end{array}$} & $\mathrm{f}$ & 102 & 6 & 22 & 8 & 2 & 11 \\
\hline & $\%$ & 67.5 & 4 & 14.6 & 5.3 & 1.3 & 7.3 \\
\hline \multirow{2}{*}{$\begin{array}{l}\text { Eğitsel denklikle ilgili } \\
\text { ulusal sistemin } \\
\text { düzenlenmesi }\end{array}$} & $\mathrm{f}$ & 116 & 9 & 18 & 2 & 3 & 3 \\
\hline & $\%$ & 76.8 & 6 & 11.9 & 1.3 & 2 & 2 \\
\hline \multirow{2}{*}{$\begin{array}{l}\text { Öğrenci seçme. } \\
\text { yerleştirme sınavları }\end{array}$} & $\mathrm{f}$ & 119 & 7 & 16 & 0 & 2 & 7 \\
\hline & $\%$ & 78.8 & 4.6 & 10.6 & 0 & 1.3 & 4.6 \\
\hline \multirow{2}{*}{$\begin{array}{l}\text { Sinav günlerinin } \\
\text { belirlenmesi }\end{array}$} & $\mathrm{f}$ & 83 & 12 & 17 & 3 & 2 & 34 \\
\hline & $\%$ & 55 & 7.9 & 11.3 & 2 & 1.3 & 22.5 \\
\hline \multirow[t]{2}{*}{ Öğrenci yükselmeleri } & $\mathrm{f}$ & 70 & 10 & 38 & 15 & 5 & 13 \\
\hline & $\%$ & 46.4 & 6.6 & 25.2 & 9.9 & 3.3 & 8.6 \\
\hline \multirow{2}{*}{$\begin{array}{l}\text { Eğitim ve öğretimle } \\
\text { ilgili veri sistemleri } \\
\text { oluşturma }\end{array}$} & $\mathrm{f}$ & 88 & 8 & 37 & 7 & 3 & 8 \\
\hline & $\%$ & 58.3 & 5.3 & 24.5 & 4.6 & 2 & 5.3 \\
\hline \multirow{2}{*}{$\begin{array}{l}\text { Başarı ölçütlerinin } \\
\text { belirlenmesi }\end{array}$} & $\mathrm{f}$ & 75 & 8 & 37 & 3 & 3 & 25 \\
\hline & $\%$ & 49.7 & 5.3 & 24.5 & 2 & 2 & 16.6 \\
\hline \multirow{2}{*}{$\begin{array}{l}\text { Öğrenci başarılarını } \\
\text { izleme ve } \\
\text { değerlendirme }\end{array}$} & $\mathrm{f}$ & 41 & 5 & 45 & 12 & 3 & 45 \\
\hline & $\%$ & 27.2 & 3.3 & 29.8 & 7.9 & 2 & 29.8 \\
\hline Toplam & & 694 & 65 & 230 & 50 & 23 & 146 \\
\hline
\end{tabular}

Ölçme Değerlendirme boyutu sekiz alt başlıkta incelenmiştir. Bu boyuta bütünsel olarak bakıldığında; okul müdürlerinin bu boyutla ilgili alınacak kararlarda karar mercii olarak uygun gördükleri en yüksek frekansa sahip birimin Bakanlık (\%57.4) olduğu 
görülmektedir. Bu dağılımı sırasıyla, İl (\%19) ve Okul (\%12) takip etmektedir. En düşük frekansın Belediye'ye (\%1.9) ait olduğu görülmektedir.

Tablo 7

Okul Müdürlerinin Eğitim Finansmanı Boyutuyla İlgili Alınacak Kararlarda Karar Mercileri Hakkındaki Görüşleri

\begin{tabular}{|c|c|c|c|c|c|c|c|}
\hline Eğitim Finansmanı & & Bakanlık & Bölge & İl & İlçe & Belediye & Okul \\
\hline \multirow[t]{2}{*}{ Maaşlar } & $\mathrm{f}$ & 105 & 5 & 15 & 8 & 7 & 11 \\
\hline & $\%$ & 69.5 & 3.3 & 9.9 & 5.3 & 4.6 & 7.3 \\
\hline \multirow[t]{2}{*}{ Ek ders ücretleri } & $\mathrm{f}$ & 94 & 6 & 16 & 12 & 8 & 15 \\
\hline & $\%$ & 62.3 & 4 & 10.6 & 7.9 & 5.3 & 9.9 \\
\hline \multirow{2}{*}{$\begin{array}{l}\text { Eğitim öğretime } \\
\text { hazırlık }\end{array}$} & $\mathrm{f}$ & 95 & 7 & 19 & 13 & 7 & 10 \\
\hline & $\%$ & 62.9 & 4.6 & 12.6 & 8.6 & 4.6 & 6.6 \\
\hline \multirow[t]{2}{*}{ Tazminatlar } & $\mathrm{f}$ & 105 & 4 & 20 & 10 & 7 & 5 \\
\hline & $\%$ & 69.5 & 2.6 & 13.2 & 6.6 & 4.6 & 3.3 \\
\hline \multirow[t]{2}{*}{ Sosyal yardımlar } & $\mathrm{f}$ & 93 & 2 & 23 & 13 & 13 & 7 \\
\hline & $\%$ & 61.6 & 1.3 & 15.2 & 8.6 & 8.6 & 4.6 \\
\hline \multirow[t]{2}{*}{ Yolluklar } & $\mathrm{f}$ & 69 & 2 & 33 & 24 & 13 & 10 \\
\hline & $\%$ & 45.7 & 1.3 & 21.9 & 15.9 & 8.6 & 6.6 \\
\hline \multirow{2}{*}{$\begin{array}{l}\text { Personel tedavi } \\
\text { giderleri }\end{array}$} & $\mathrm{f}$ & 81 & 4 & 29 & 20 & 9 & 8 \\
\hline & $\%$ & 53.6 & 2.6 & 19.2 & 13.2 & 6 & 5.3 \\
\hline \multirow{2}{*}{$\begin{array}{l}\text { Yiyecek malzemesi } \\
\text { giderleri }\end{array}$} & $\mathrm{f}$ & 53 & 14 & 35 & 18 & 17 & 14 \\
\hline & $\%$ & 35.1 & 9.3 & 23.2 & 11.9 & 11.3 & 9.3 \\
\hline \multirow{2}{*}{$\begin{array}{l}\text { Isınma malzemesi } \\
\text { giderleri }\end{array}$} & $\mathrm{f}$ & 53 & 10 & 31 & 23 & 19 & 15 \\
\hline & $\%$ & 35.1 & 6.6 & 20.5 & 15.2 & 12.6 & 9.9 \\
\hline \multirow{2}{*}{$\begin{array}{l}\text { Kütüphane } \\
\text { malzemesi giderleri }\end{array}$} & $\mathrm{f}$ & 48 & 5 & 38 & 22 & 19 & 19 \\
\hline & $\%$ & 31.8 & 3.3 & 25.2 & 14.6 & 12.6 & 12.6 \\
\hline \multirow[t]{2}{*}{ Kırtasiye giderleri } & $\mathrm{f}$ & 42 & 5 & 40 & 26 & 17 & 21 \\
\hline & $\%$ & 27.8 & 3.3 & 26.5 & 17.2 & 11.3 & 13.9 \\
\hline \multirow{2}{*}{$\begin{array}{l}\text { Laboratuar } \\
\text { malzemesi giderleri }\end{array}$} & $\mathrm{f}$ & 52 & 4 & 39 & 22 & 16 & 18 \\
\hline & $\%$ & 34.4 & 2.6 & 25.8 & 14.6 & 10.6 & 11.9 \\
\hline \multirow{2}{*}{$\begin{array}{l}\text { Öğrenci giyecek } \\
\text { malzemesi giderleri }\end{array}$} & $\mathrm{f}$ & 50 & 4 & 39 & 24 & 16 & 18 \\
\hline & $\%$ & 33.1 & 2.6 & 25.8 & 15.9 & 10.6 & 11.9 \\
\hline \multirow{2}{*}{$\begin{array}{l}\text { Personel giyecek } \\
\text { malzemesi giderleri }\end{array}$} & $\mathrm{f}$ & 44 & 9 & 37 & 21 & 19 & 21 \\
\hline & $\%$ & 29.1 & 6 & 24.5 & 13.9 & 12.6 & 13.9 \\
\hline
\end{tabular}




\begin{tabular}{|c|c|c|c|c|c|c|c|}
\hline \multirow{2}{*}{$\begin{array}{l}\text { Temizlik malzemesi } \\
\text { giderleri }\end{array}$} & $f$ & 43 & 6 & 34 & 27 & 18 & 23 \\
\hline & $\%$ & 28.5 & 4 & 22.5 & 17.9 & 11.9 & 15.2 \\
\hline \multirow{2}{*}{$\begin{array}{l}\text { Küçük bina bakım- } \\
\text { onarım giderleri }\end{array}$} & $\mathrm{f}$ & 29 & 5 & 46 & 24 & 31 & 16 \\
\hline & $\%$ & 19.2 & 3.3 & 30.5 & 15.9 & 20.5 & 10.6 \\
\hline \multirow[t]{2}{*}{ Elektrik ve su } & $\mathrm{f}$ & 31 & 5 & 41 & 29 & 32 & 13 \\
\hline & $\%$ & 20.5 & 3.3 & 27.2 & 19.2 & 21.2 & 8.6 \\
\hline \multirow[t]{2}{*}{ Taşıma } & $f$ & 31 & 5 & 40 & 37 & 27 & 11 \\
\hline & $\%$ & 20.5 & 3.3 & 26.5 & 24.5 & 17.9 & 7.3 \\
\hline \multirow{2}{*}{$\begin{array}{l}\text { Öğrenci tedavi } \\
\text { giderleri }\end{array}$} & $f$ & 45 & 3 & 33 & 38 & 21 & 11 \\
\hline & $\%$ & 29.8 & 2 & 21.9 & 25.2 & 13.9 & 7.3 \\
\hline \multirow{2}{*}{$\begin{array}{l}\text { Öğrenci burs-harç } \\
\text { kredileri }\end{array}$} & $f$ & 60 & 5 & 32 & 24 & 18 & 12 \\
\hline & $\%$ & 39.7 & 3.3 & 21.2 & 15.9 & 11.9 & 7.9 \\
\hline \multirow[t]{2}{*}{ Demirbaş alımı } & $\mathrm{f}$ & 59 & 5 & 31 & 26 & 17 & 13 \\
\hline & $\%$ & 39.1 & 3.3 & 20.5 & 17.2 & 11.3 & 8.6 \\
\hline \multirow{2}{*}{$\begin{array}{l}\text { Kamulaştırma } \\
\text { giderleri }\end{array}$} & $\mathrm{f}$ & 80 & 3 & 40 & 6 & 20 & 2 \\
\hline & $\%$ & 53 & 2 & 26.5 & 4 & 13.2 & 1.3 \\
\hline \multirow{2}{*}{$\begin{array}{l}\text { Yeni bina } \\
\text { yaptırılması/ satın } \\
\text { alınması }\end{array}$} & $f$ & 69 & 6 & 50 & 9 & 17 & 0 \\
\hline & $\%$ & 45.7 & 4 & 33.1 & 6 & 11.3 & 0 \\
\hline \multirow[t]{2}{*}{ Büyük onarımlar } & $f$ & 59 & 5 & 56 & 11 & 17 & 3 \\
\hline & $\%$ & 39.1 & 3.3 & 37.1 & 7.3 & 11.3 & 2 \\
\hline \multirow[t]{2}{*}{ Donatım giderleri } & $\mathrm{f}$ & 48 & 4 & 54 & 19 & 19 & 7 \\
\hline & $\%$ & 31.8 & 2.6 & 35.8 & 12.6 & 12.6 & 4.6 \\
\hline \multirow{2}{*}{$\begin{array}{l}\text { Harcamalarin } \\
\text { denetlenmesi }\end{array}$} & $\mathrm{f}$ & 47 & 2 & 61 & 26 & 11 & 4 \\
\hline & $\%$ & 31.1 & 1.3 & 40.4 & 17.2 & 7.3 & 2.6 \\
\hline Toplam & & 1554 & 135 & 932 & 532 & 435 & 307 \\
\hline
\end{tabular}

Eğitim Finansmanı boyutu yirmi altı alt başlıkta incelenmiştir. Bu boyuta bütünsel olarak bakıldığında; okul müdürlerinin bu boyutla ilgili alınacak kararlarda karar mercii olarak uygun gördükleri en yüksek frekansa sahip birimin Bakanlık (\%39.8) olduğu görülmektedir. Bu dağılımı sırasıyla, İl (\%23.9) ve İlçe (\%13.6) takip etmektedir. En düşük frekansın Bölge'ye (\%3.46) ait olduğu görülmektedir.

Okul yöneticilerinin yerinden yönetim hakkındaki görüşleri ile kıdem değişkeni arasında sadece 'eğitim işgörenlerine ödenecek ücretlerin kararlaştırılması' hususunda anlamlı bir farklılık tespit edilmiştir. 
Tablo 8

Okul Yöneticilerinin Mesleki Kıdemlerine Göre Eğitim İsgörenlerine Ödenecek Ücretlerin Kararlaştırılmasına İlişkin Görüşleri- Kay Kare Testi Sonuçları

\begin{tabular}{|c|c|c|c|c|c|c|c|c|c|c|c|c|c|c|c|}
\hline \multirow{2}{*}{ Kıdem } & \multicolumn{2}{|c|}{ Bakanlık } & \multicolumn{2}{|c|}{ Bölge } & \multicolumn{2}{|c|}{ İl } & \multicolumn{2}{|c|}{ İlçe } & \multicolumn{2}{|c|}{$\begin{array}{c}\text { Belediy } \\
\mathrm{e}\end{array}$} & \multicolumn{2}{|c|}{ Okul } & \multirow[t]{2}{*}{$\begin{array}{c}\text { Topla } \\
\text { m }\end{array}$} & \multirow[t]{2}{*}{$\mathrm{X}^{2}$} & \multirow[t]{2}{*}{$\mathrm{P}$} \\
\hline & $\mathrm{f}$ & $\%$ & $\mathrm{f}$ & $\%$ & $\mathrm{f}$ & $\%$ & $\mathrm{f}$ & $\%$ & $\mathrm{f}$ & $\%$ & $\mathrm{f}$ & $\%$ & & & \\
\hline $\begin{array}{c}1-10 \\
\text { y1l }\end{array}$ & 2 & $\begin{array}{c}50 . \\
0\end{array}$ & 0 & 0 & 2 & $\begin{array}{c}50 . \\
0\end{array}$ & 0 & 0 & 0 & 0 & 0 & 0 & 4 & & \\
\hline $\begin{array}{c}11-20 \\
\text { yll }\end{array}$ & $\begin{array}{l}4 \\
6\end{array}$ & $\begin{array}{c}52 . \\
3\end{array}$ & 3 & 3.4 & $\begin{array}{l}1 \\
1\end{array}$ & $\begin{array}{c}12 . \\
5\end{array}$ & 3 & 3.4 & 3 & 3.4 & $\begin{array}{l}2 \\
2\end{array}$ & $\begin{array}{c}25 . \\
0\end{array}$ & 88 & 27.7 & .02 \\
\hline $\begin{array}{c}21-30 \\
\text { yll }\end{array}$ & $\begin{array}{l}2 \\
0\end{array}$ & $\begin{array}{c}44 . \\
4\end{array}$ & 5 & $\begin{array}{c}11 . \\
1\end{array}$ & $\begin{array}{l}1 \\
0\end{array}$ & $\begin{array}{c}22 . \\
2\end{array}$ & 5 & $\begin{array}{c}11 . \\
1\end{array}$ & 3 & 6.7 & 2 & 4.4 & 44 & 3 & 3 \\
\hline $\begin{array}{c}31 \text { yll } \\
\text { ve üstü }\end{array}$ & 5 & $\begin{array}{c}35 . \\
7\end{array}$ & 1 & 7.1 & 4 & $\begin{array}{c}28 . \\
6\end{array}$ & 2 & $\begin{array}{c}14 . \\
3\end{array}$ & 2 & 14.3 & 0 & 0 & 14 & & \\
\hline $\begin{array}{l}\text { Topla } \\
\text { m }\end{array}$ & $\begin{array}{l}7 \\
3\end{array}$ & $\begin{array}{c}48 . \\
3\end{array}$ & 9 & 5.9 & $\begin{array}{l}2 \\
7\end{array}$ & $\begin{array}{c}17 . \\
8\end{array}$ & $\begin{array}{l}1 \\
0\end{array}$ & 6.6 & 8 & 5.2 & $\begin{array}{l}2 \\
4\end{array}$ & $\begin{array}{c}15 . \\
8\end{array}$ & 151 & & \\
\hline
\end{tabular}

Tablo 8'deki kay kare analizine baktığımızda kıdem değişkeninin okul yöneticilerinin eğitim işgörenlerine ödenecek ücretlerin kararlaştırılması konusunda anlamlı bir fark olduğu görülmüştür, $\mathrm{X}^{2}(\mathrm{sd}=15, \mathrm{n}=151)=27.73, \quad \mathrm{P}<.05$. Eğitim işgörenlerine ödenecek ücretlerin kararlaştırılması konusunda Bakanlık birimini karar merci olarak gören 11-20 yıl aralığında kıdeme sahip okul yöneticilerinin oranı (\% 52.3), diğer kıdem aralığındaki okul yöneticilerine göre anlamlı derecede yüksektir.

\section{Tartışma ve Sonuç}

Eğitimin yerinden yönetimi konusunda eğitim kurumlarında görev yapan eğitim yöneticilerinin yerinden yönetim anlayışına ilişkin görüşlerini tespit etmek amacıyla yapılan bu çalışmada yönetim boyutu altı alt başlıkta incelenmiştir. Bu boyuta bütünsel olarak bakıldığında; okul müdürlerinin bu boyutla ilgili alınacak kararlarda karar mercii olarak uygun gördükleri en yüksek frekansa sahip birimin Bakanlık (\%42.7) olduğu görülmektedir. En düşük frekansın Belediye’ye (\%2.09) ait olduğu görülmektedir.

Turan, Yücel, Karataş ve Demirhan (2010) tarafından yapılan 'Okul Müdürlerinin Yerinden Yönetim Hakkındaki Görüşleri' konulu çalışma bulguları da yönetim boyutunda bu sonucu desteklemektedir. Ölmez ve Tonbul (2011) tarafindan 'Eğitim Yönetiminin Yerelleşmesi Sürecinde Bir Uygulama: Eğitim Bölgeleri Danışma Kurulları' isimli çalışma da yerel yönetime henüz hazır olunmadığını göstermektedir. Bunun sebebi idarenin tek merkezde toplanmasıyla daha kolay sağlanabileceği ve idarenin ve kamu görevlilerinin tarafsızlığının yerel etkilerden uzak olmaları nedeniyle daha kolay sağlanabileceği olabilir.

Okulun Örgütlenmesi boyutu dokuz alt başlıkta incelenmiştir. Bu boyuta bütünsel olarak bakıldığında; okul müdürlerinin bu boyutla ilgili alınacak kararlarda karar mercii 
olarak uygun gördükleri en yüksek frekansa sahip birimin Okul (\%28.4) olduğu görülmektedir. En düşük frekansın Belediye’ye (\%4.12) ait olduğu görülmektedir. Turan, Yücel, Karataş ve Demirhan (2010) tarafından yapılan 'Okul Müdürlerinin Yerinden Yönetim Hakkındaki Görüşleri’ konulu çalışma bulguları da okulun örgütlenmesi boyutunda karar mercii olarak en yüksek frekansa sahip birimin Okul olduğunu göstermektedir. Ekşi ve Kaya'nın (2011) yaptığ1 'Okul Merkezli Yönetim Sistemine İlişkin Öğretmen Görüşleri başlıklı çalışmada' öğretmenlerin okul merkezli yönetim (OMY) konusunda OMY sistemlerine ilişkin grup içi katılımların yüksek olduğu görülmektedir. Bunun sebebi de okulun eğitim programının yerel gereksinim ve özelliklere uygun olarak geliştirilebileceği düşüncesi olabilir.

İnsan Kaynakları Yönetimi boyutu on iki alt başlıkta incelenmiştir. Bu boyuta bütünsel olarak bakıldığında; okul müdürlerinin bu boyutla ilgili alınacak kararlarda karar mercii olarak uygun gördükleri en yüksek frekansa sahip birimin Bakanlık (\%31.1) olduğu görülmektedir. En düşük frekansın Belediye’ye (\%2.92) ait olduğu görülmektedir. Turan, Yücel, Karataş ve Demirhan (2010) tarafindan yapılan 'Okul Müdürlerinin Yerinden Yönetim Hakkındaki Görüşleri’ konulu çalışmanın insan kaynakları boyutu bulgularında en yüksek frekans okuldur. Çalışma bu boyutu ile yaptığımız çalışmadan farklılık göstermektedir. Arslan ve Atasayar' in (2008) yaptığ 1"Millî Eğitim Bakanlığ 1 Taşra Örgütü Yöneticilerinin Yerelleşme Konusundaki Görüşleri” başlıklı çalışmada da Personeli işe alma, işten çıkarma boyutunda merkezi kaynakların değil yerel kaynakların kullanılmasını önermesi bakımından çalışmamızdan farklılık göstermektedir.

Eğitim Programı ve Öğretimi boyutu on dört alt başlıkta incelenmiştir. Bu boyuta bütünsel olarak bakıldığında; okul müdürlerinin bu boyutla ilgili alınacak kararlarda karar mercii olarak uygun gördükleri en yüksek frekansa sahip birimin Bakanlık (\%50.5 ) olduğu görülmektedir. En düşük frekansın Belediye'ye (\%2.6) ait olduğu görülmektedir. Turan, Yücel, Karataş ve Demirhan (2010) tarafindan yapılan 'Okul Müdürlerinin Yerinden Yönetim Hakkındaki Görüşleri' konulu çalışmanın Eğitim Programı ve Öğretimi bulguları da en yüksek ve en düşük frekans verilerinde aynı sonuçları vermiştir. Arslan ve Atasayar'ın (2008) yaptığg "Millî Eğitim Bakanlığı Taşra Örgütü Yöneticilerinin Yerelleşme Konusundaki Görüşleri” başlıklı çalışma Temel dersler, Yardımcı dersler, Ders programlarının hazırlanması, geliştirilmesi boyutunda merkezi kaynakların değil yerel kaynakların kullanılmasını önermesi bakımından çalışmamızdan farklılık göstermektedir.

Ölçme Değerlendirme boyutuna bütünsel olarak bakıldığında; okul müdürlerinin bu boyutla ilgili alınacak kararlarda karar mercii olarak uygun gördükleri en yüksek frekansa sahip birimin Bakanlık (\%57.4) olduğu görülmektedir. Bu dağılımı sırasıyla, İl (\%19) ve Okul (\%12) takip etmektedir. En düşük frekansın Belediye’ye (\%1.9) ait olduğu görülmektedir. Yaptı̆̆ımız çalışmanın bulguları, Turan, Yücel, Karataş ve Demirhan (2010) tarafından yapılan çalışmanın bulgularıyla tutarlıdır. Özdemir(2013)' in 'Resmi Genel Liselerin Eğitsel Amaçlarının Misyon Cümlelerine Dayalı Olarak Çözümlenmesi’ adlı çalışmasında genel liselerin eğitime, öğrencilerin bireysel kapasitelerini ve merkezi 
ölçme ve değerlendirme sınavlarında rekabet edebilirliklerini güçlendirmenin bir arac1 olarak baktıkları sonucunu ortaya çıkarması bakımından çalışmamızı desteklemedir.

Eğitim Finansmanı boyutuna bütünsel olarak bakıldığında; okul müdürlerinin bu boyutla ilgili alınacak kararlarda karar mercii olarak uygun gördükleri en yüksek frekansa sahip birimin Bakanlık (\%39.8) olduğu görülmektedir. Bu dağılımı sırasıyla, İl (\%23.9) ve İlçe (\%13.6) takip etmektedir. En düşük frekansın Bölge'ye (\%3.46 ) ait olduğu görülmektedir. Turan, Yücel, Karataş ve Demirhan (2010) tarafından yapılan çalışmanın eğitim finansmanı boyutunda ise en yüksek frekans İl birimine aittir. Kaya, Kaya ve Nural'ın (2013) 'Okul Aile Birliklerinin İşleyişi, Sorunlarına İlişkin Yöneticilerin, Okul Aile Birliği Üyelerinin Görüşleri' adlı çalışmalarında okul müdürleri; 'Sizce eğitim harcamaları kimler tarafından karşılanmalıdır?' sorusuna en çok Milli Eğitim Bakanlığ1 cevabını vermişlerdir. Yine Menduhoğlu ve Meriç’in (2012) yaptığı çalışmada okul müdürleri, okulların bütçesinin olmadığından, en küçük ihtiyaçlarını bile İl Milli Eğitim Müdürlükleri gibi başka birimlerce karşılanmasını beklemek durumunda kaldıklarını ifade etmişlerdir.

Okul yöneticilerinin yerinden yönetim hakkındaki görüşleri ile kıdem değişkeni arasında sadece 'eğitim işgörenlerine ödenecek ücretlerin kararlaştırılması' hususunda anlamlı bir farklılık çıkmıştır. Bu konuda, Bakanlık birimini karar merci olarak gören 1120 yıl aralığında kıdeme sahip okul yöneticilerinin oranı (\%52.3), diğer kıdem aralığındaki okul yöneticilerine göre anlamlı derecede yüksektir.

Bulgular genel olarak değerlendirildiğinde örneklem dahilindeki okul yöneticilerinin eğitimle ilgili kararlara katılmada karar merci olarak ağırlıklı olarak Bakanlık olmak üzere Okul ve İl birimlerine ağırlık vermektedir. Bölge, İlçe ve Belediyelere pek fazla görev biçmedikleri görülmektedir. Bu da okul yöneticilerinin yerelleşmeye pek sıcak bakmadıkları şeklinde yorumlanabilir. Türkiye'nin üniter yapıya sahip bir devlet olması, merkezi yönetime ağırlık vermelerinde bir etken olabilir. Buna göre okul yöneticilerinde, eğitimin yerinden yönetimi ve yetki devri konularında bilgi yetersizliği olduğu düşünülmektedir. Bu eksikliklerin giderilmesi için bu konularda daha fazla tartışma ortamları yaratılarak, konuyla ilgili yayın sayısının artırılması gerekmektedir. Eğitim Bölgesi Danışma Kurullarının geliştirilmesi ve yerelleşme konusunda alt birimlerle üst birimleri arasında bilgi akışını sağlayan bir kurum haline getirilmesi gerekmektedir. Yerelleşeme sürecinde yaşanması olası problemleri ve ihtiyaç duyulabilecek alt yapı özelliklerinin belirlenmesi amacıyla bağımsız müdürlüklerden (ilçe ve/veya illerden) oluşan pilot deneme bölgeleri oluşturulması gerekmektedir. Eğitimde yerelleşme ve yetki devri konularında akademisyenler aracılığıyla hizmet içi eğitim seminerleri, konferans ve paneller düzenlenmeli etkin katılım sağlanmalıdır. 


\section{Kaynakça}

Ainley, J., \& McKenzie, P. (2000). School governance: research on educational and management issues. International Education Journal, 1(3), 139-151.

Busemeyer, M. R. (2012, April). Two decades of decentralization in education governance: Lessons learned and future outlook for local stakeholders. In Presentation delivered at OECD conference, 'Effective local governance in education.

Arslan, M. M., \& Atasayar, H. H. (2008). Milli Eğitim Bakanlığg taşra örgütü yöneticilerinin yerelleşme konusundaki görüşleri. Ankara Üniversitesi Ĕgitim Bilimleri Fakültesi Dergisi, 41(2), 59-79.

Arslan, Y. (2013). Yerel yönetimler ve eğitim hizmetleri ilişkisi (Yayınlanmamış Yüksek Lisans Tezi). İstanbul Aydın Üniversitesi, İstanbul.

Bray, M. (1991). Centralization versus decentralization in educational administration: regional issues. Educational Policy, 5(4), 371-385.

Bursalioğlu, Z. (2005). Okul yönetiminde yeni yapı ve davranış. Ankara: Pegem A Yayıncilik.

Çınarlı, S. (2011). İskoçya yerinden yönetim deneyimine genel bir bakış. Ege Akademik Bakış, 11(2), 299-307.

Ekşi, H. \& Kaya, M. (2011). Okul merkezli yönetim sistemine ilişkin öğretmen görüşleri. Atatürk Ĕ̌itim Fakültesi Eğitim Bilimleri Dergisi, 33, 45-60.

Erençin, A. \& Yolcu, V. (2008). Türkiye'de sağlık hizmetlerinin dönüşümü ve yerinden yönetimi. Memleket Siyaset Yönetim, 3(6), 118-136.

Günal, V. A. (2010). Türkiye'de merkezi yönetim- belediye ilişkileri 1999-2006 arası siyasal, yönetsel, ekonomik ilişkiler (Yayınlanmamış Doktora Tezi). Akdeniz Üniversitesi, Antalya.

Hanson, E. M. (1997). Educational decentralization: Issues and challenges. InterAmerican Dialogue: Corporation for Development Research. http://archives.thedialogue.org/PublicationFiles/PREAL\%209-English.pdf adresinden 10.12.2016 tarihinde erişilmiştir.

Karasar, N. (2005). Bilimsel araştırma yöntemleri. Ankara: Nobel Yayın-Dağıtım.

Kıran, H. (2001). Milli Eğitim Bakanlığı taşra örgütü yöneticilerinin eğitimde yerinden yönetime ilişkin tutumları. Pamukkale Üniversitesi Eğitim Fakültesi Dergisi, 9(9), 19.

Levy, M. (1966). Modernization and the structure of societies: a setting for international affairs. Princeton, New Jersey: Princeton University Press.

Lunenberg, F. C. \& C.Ornstein, A. (2013). Eğitim yönetimi (G. Arastaman, Çev.). Ankara: Nobel Akademik Yayıncılık.

Memduhoğlu, H. B. \& Meriç, E. (2014). Okul müdürlerinin eğitim yönetiminin işlevleri bağlamında yönetim sürecinde karşılaştıkları temel sorunlar. Uluslararası Sosyal Araştırmalar Dergisi, 7(33), 653-666. 
Nural, E., Kaya, C. D. \& Kaya, Y. (2013). Okul aile birliklerinin işleyişi, sorunlarına ilişkin yöneticilerin, okul aile birliği üyelerinin görüşleri. Ĕ̆itim ve Öğretim Araştırmaları Dergisi, 2(4), 58-69.

Ortaç, A. (2003). İlköğretim kurumlarındaki yönetici yardımcılarının yetki devri ile ilgili görüş ve beklentileri (Yayınlanmamış Yüksek Lisans Tezi). Trakya Üniversitesi, Edirne.

Ölmez, Ö. \& Tonbul, Y. (2011). Eğitim yönetiminin yerelleşmesi sürecinde bir uygulama: eğitim bölgeleri danışma kurulları. Mehmet Akif Ersoy Üniversitesi Ĕ̈itim Fakültesi Dergisi, 1(21), 153-179.

Özdemir, M. (2013). Resmi genel liselerin eğitsel amaçlarının" misyon" cümlelerine dayalı olarak çözümlenmesi. Hacettepe Üniversitesi Eğitim Fakültesi Dergisi, 28(1), 281-293.

Özgen, V. (2011). Eğitim hizmetlerinde yerelleşme ve hizmet kalitesi (Yayınlanmamış Yüksek Lisans Tezi). Aydın Adnan Menderes Üniversitesi, Aydın.

Parlak, B. (2014). Avrupa Birliği perspektifinden merkezi yönetim-yerel yönetim ilişkileri. Tesam Akademi Dergisi, 1(1), 7-40.

Büyüköztürk, Ş. (2014). Sosyal bilimler için veri analizi el kitabı. Ankara: Pegem Akademi.

Şişman, M., \& Turan, S. (2003). Eğitimde yerelleşme ve demokratikleşme çabaları: teorik bir çözümleme. Kuram ve Uygulamada Eğitim Yönetimi, 34, 300-315.

Taşar, H. H. (2009). Merkeziyetçi yönetim yapısının kamu okulları üzerinde bıraktığı olumsuz etkiler. Adryaman Üniversitesi Sosyal Bilimler Enstitüsü Dergisi, 2(2), 108119.

Taşdan, M., Tösten, R., Bulut, K., \& Karakaya, V. (2013). Okul yöneticilerinin ilköğretim okullarında karşılaşılan sorunlarına ilişkin görüşleri. Eğitim Bilimleri ve Uygulama Dergisi, 12(24), 95-113.

Tural, N. K. (2002). Eğitim finansmanı. Ankara: Anı Yayıncılık.

Turan, S., Yücel, C., Karataş, E., \& Demirhan, G. (2010). Okul müdürlerinin yerinden yönetim hakkındaki görüşleri. Uşak Üniversitesi Sosyal Bilimler Dergisi, 3(1), 1-18.

Turkoglu, R. (2004). Eğitimde yerelleşme sorununa kamu yönetimi temel kanunu tasarısı ve yerel yönetim yasa tasarısının getirdiği çözümler konusunda yerel yöneticilerin görüşleri. Inönü Üniversitesi Eğitim Fakültesi Dergisi, 5(8).

Usluel, Y. (1995). Milli eğitim bakanlı̆̆l merkez örgütü yöneticilerinin yerelleşme konusundaki görüşleri (Yayınlanmamış Doktora Tezi). Hacettepe Üniversitesi, Ankara.

Welsch, T., \& McGinn, N. F. (1999). Decentralization of Education: Why, When, What and How? Paris: The United Nations Educational, Scientific and Cultural Organization (UNESCO).

Winkler, D., \& Yeo, B. L. (2007). Identifying the impact of education decentralization on the quality of education. Washington DC: USAID. 
Yalçınkaya, M. (2004). Okul merkezli yönetim. Ege Eğitim Dergisi, 5(2), 21-34.

Yavuz, Y. (2003). Lise Yönetici ve Öğretmenlerinin Yerinden ve Merkezden Yönetim Yönelimlerinin Karar Verme Sürecine Etkileri. Ege Eğitim Dergisi, 3(2), 25-35.

Yazıcıŏlu, Y. \& Erdoğan, S. (2004). SPSS uygulamalı bilimsel çalışma yöntemleri. Ankara: Detay Yayınc1lık. 